\title{
PEMBELAJARAN AKTIF UNTUK MENINGKATKAN KEMAMPUAN BERFIKIR TINGKAT TINGGI MELALUI KETRAMPILAN MENYELESAIKAN MASALAH PADA PERKULIAHAN KALKULUS LANJUT
}

\author{
Rizqi Tresnaningsih \\ FPMIPA IKIP PGRI Madiun
}

Abstrak:

Mata kuliah kalkulus lanjut merupakan salah satu mata kuliah yang menitik beratkan pada kemampuan memecahkan masalah yang melibatkan banyak materi prasyarat. Peranan dari mata kuliah prasyarat sangat penting dan mendominasi terhadap hasil perhitungan. Mata kuliah kalkulus lanjut menuntut mahasiswa untuk selalu meningkatkan cara berfikir mahasiswa, sehingga mahasiswa dapat berfikir lebih tinggi lagi dalam menyelesaikan persoalan kalkulus lanjut yang cukup kompleks. Pembelajaran Berbasis Masalah merupakan metode pembelajaran aktif yang digunakan untuk masalah terstruktur yang merupakan tanggapan dari hasil pembelajaran. Pada model pengajaran ini, digunakan untuk menyelesaikan masalah mempunyai struktur yang kompleks yang tidak cukup bila dikerjakan dengan algoritma yang sederhana. Penelitian ini adalah Penelitian Tindakan Kelas (Classroom Action Research). Penelitian tindakan kelas adalah suatu penyelidikan secara sistematis dan terencana untuk memperbaiki pembelajaran dengan jalan mengadakan perbaikan atau perubahan dan mempelajari akibat yang akan ditimbulkan. Untuk memperoleh data yang sesuai dengan permasalahan dan tujuan penelitian maka penelitian tindakan kelas ini akan dilaksanakan dalam 2 siklus. Masing-masing siklus terdiri dari 4 tahap yaitu tahap perencanaan (planning), tahap pelaksanaan (action), tahap pengamatan (observation) dan tahap refleksi (reflection). Dengan menggunakan pembelajaran berbasis masalah hasil observasi setiap indikator pada siklus I masih mempunyai nilai rendah. Kenaikan nilai mahasiswa mengindikasikan bahwa terdapat peningkatan aktifitas intelektual mahasiswa, yaitu pada tahap berdiskusi. Pada kegiatan berdiskusi, mahasiswa dapat memberikan masukan, ide, saran dan gagasan-gagasan yang menurut mereka benar, meskipun belum diketahui kebenaranya tersebut, akan tetapi dengan melalui tahapan pada sintaksis model pembelajaran tersebut, mahasiswa mempunyai ide, gagasan yang akan meningkatkan kemampuan berfikir tingginya. Pada siklus ke dua ini, mahasiswa telah dapat menunjukkan peningkatannya dalam berfikir, sehingga apabila diterapkan model pembelajaran berbasis masalah ini secara kontinu, maka akan diindikasi dengan peningkatan berfikir mahasiswa dalam menyelesaikan masalah kalkulus lanjut.

Kata Kunci : Pembelajaran Berbasis Masalah, Berfikir Tingkat Tinggi, Kalkulus Lanjut 


\section{A. Pendahuluan}

Selama beberapa tahun terakhir ini, ada penekanan yang semakin besar pada pengajaran ketrampilan berfikir dan mengatasi masalah di sekolah. Hal ini disebabkan oleh berbagai penelitian yang menunjukkan adanya keterkaitan antara ketrampilan berfikir murid dan prestasinya di berbagai mata pelajaran di sekolah misalnya matematika. Sebagian besar lainnya disebabkan adanya peubahan di masyarakat, khususnya perubahan yang bergerak ke arah masyarakat di mana pengetahuan dan informasi menjadi semakin kompleks dan semakin cepat. Hal ini berarti bahwa memproses sejumlah besar pengetahuan saja tidak cukup. Anakanak dan orang dewasa akan perlu memiliki ketrampilan untuk membuat pilihanpilihan dan mengatasi berbagai masalah dengan menggunakan penalaran logis (Resnick, 1987. Dalam Effective Teaching. Daniel Muijs dan David Reynolds. 2008)

Banyak program dikembangkan untuk meningkatkan ketrampilan berfikir murid, salah satunya melalui pendekatan yang populer yaitu adalah mengajarkan sejumlah ketrampilan menyelesaikan masalah kepada mahasiswa. Pembelajaran Berbasis Masalah merupakan metode pembelajaran aktif yang digunakan untuk masalah terstruktur yang merupakan tanggapan dari hasil pembelajaran. Pada model pengajaran ini, digunakan untuk menyelesaikan masalah mempunyai struktur yang kompleks yang tidak cukup bila dikerjakan dengan algoritma yang sederhana. Pada Pembelajaran Berbasis Masalah ini, siswa diberi kesempatan untuk mengembangkan kemampuannya sendiri. Pembelajaran berbasis masalah yang digunakan dilakukan dengan pendekatan metakognitif, yaitu suatu pendekatan yang mencakup pengetahuan tentang proses berfikir kita sendiri, regulasi diri dan memantau apa yang sedang dikerjakan, mengapa mengerjakan itu dan apa yang sedang kita kerjakan dapat membantu mengatasi masalah.

Mata kuliah kalkulus lanjut merupakan salah satu mata kuliah yang menitik beratkan pada kemampuan memecahkan masalah. Hal tersebut dikarenakan mata kuliah kalkulus lanjut merupakan mata kuliah yang mempunyai materi prasyarat mata kuliah geometri analitik, yang digunakan untuk menggambar pada ruang dimensi tiga pada suatu benda pejal ketika akan mencari volum ataupun luas permukaan ataupun perhitungan pengintegralan yang lainnya. Selain mata kuliah geometri analitik, prasyarat yang lain adalah mata kuliah kalkulus 1 dan 2, yang terkait dengan penghitungan integralnya baik pada saat mencari volum, luas permukaan ataupun perhitungan lainnya. Peranan dari mata kuliah prasyarat sangat penting dan mendominasi terhadap hasil perhitungan. Perkuliahan pada mata kuliah ini, menuntut mahasiswa untuk mampu menganalisis, dan menggunakan konsep yang telah dipelajari pada geometri analit, kalkulus 1 dan kalkulus 2.

Kesadaran mahasiswa untuk belajar kalkulus lanjut juga masih tergolong rendah, hal tersebut dapat dilihat dari hasil UAS semester Genap yang lalu. Nilai rata-rata kalkulus lamjut dari kelas 4A sampai 4D adalah sebagai berikut: 
Tabel 1.1

\begin{tabular}{|l|l|l|}
\hline NO & KELAS & Nilai Rata-rata tiap kelas \\
\hline 1 & $4 \mathrm{~A}$ & 60,44 \\
\hline 2 & $4 \mathrm{~B}$ & 61,75 \\
\hline 3 & $4 \mathrm{C}$ & 63,95 \\
\hline 4 & $4 \mathrm{D}$ & 63,1 \\
\hline Rata-rata & 62,31 \\
\hline
\end{tabular}

Pada tabel $1.1 \mathrm{di}$ atas nampak, mahasiswa dari keempat kelas memperoleh rata-rata kelas 62,31, dari hasil nilai rata-rata kelas tersebut tentu saja kurang memuaskan, hal terserbut dimungkinkan pembelajaran yang dilakukan masih kurang sesuai dengan kondisi kelas. Peneliti juga menilai bahwa ketika perkuliahan pada semester-semester yang telah dilaksanakan, mahasiswa masih merasa kesulitan dalam menggambar dan menghitung integral, sehingga pada pelaksanaan perkuliahan peneliti akan mengingatkan kembali sedikit tentang materi prasyarat. Dari sini peneliti menilai pada perkuliahan kalkulus lanjut akan lebih sesuai jika dilakukan dengan menggunakan model pengajaran pembelajaran berbasis masalah.

\section{B. Metode Penelitian}

Penelitian ini adalah Penelitian Tindakan Kelas (Classroom Action Research). Penelitian tindakan kelas adalah suatu penyelidikan/kajian secara sistematis dan terencana untuk memperbaiki pembelajaran dengan jalan mengadakan perbaikan atau perubahan dan mempelajari akibat yang akan ditimbulkan (Hobri, 2007:2).

Untuk memperoleh data yang sesuai dengan permasalahan dan tujuan penelitian maka penelitian tindakan kelas ini akan dilaksanakan dalam 3 siklus. Masing-masing siklus terdiri dari 4 tahap yaitu tahap perencanaan (planning), tahap pelaksanaan (action), tahap pengamatan (observation) dan tahap refleksi (reflection). 
Gambaran dari ketiga siklus di atas sebagai berikut.

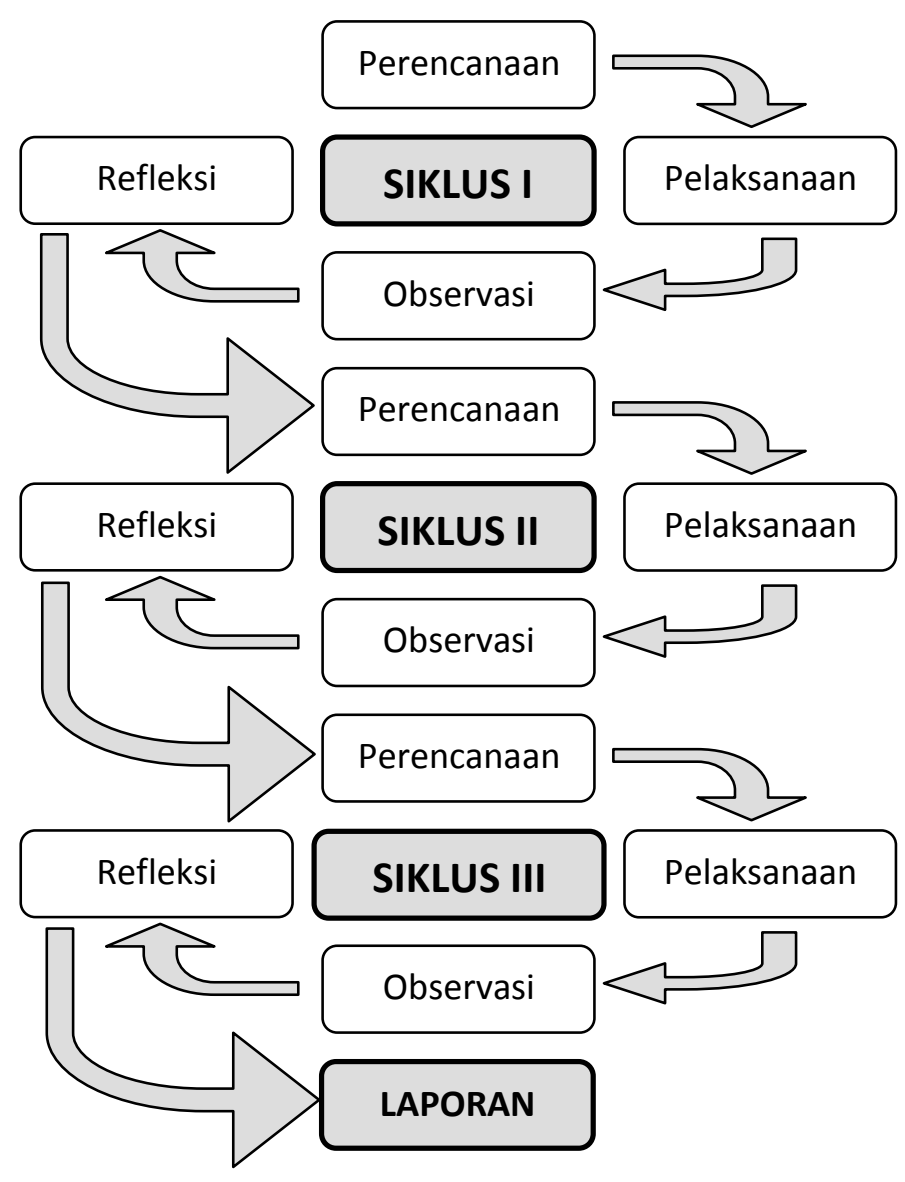

Gambar 1.1 Alur Pelaksanaan Penelitian Tindakan Kelas

Sumber: Suharsini Arikunto (2006:16)

Adapun uraian dari ketiga siklus tersebut adalah sebagai berikut.

\section{SIKLUS I}

a. Perencanaan (planning)

Perencanaan tindakan yang peneliti lakukan adalah sebagai berikut.

1) Peneliti menyiapkan perangkat pembelajaran diantaranya silabus dan satuan acara perkuliahan (SAP) melalui model pengajaran Pembelajaran Berbasis Masalah

2) Peneliti mempersiapkan materi pengajaran yang akan diajarkan dalam pelaksanaan tindakan.

3) Peneliti menyusun soal-soal untuk tugas kelompok dan tugas individu untuk mahasiswa. 
4) Peneliti menyiapkan lembar observasi berupa lembar chek list untuk mengetahui proses berfikir mahasiswa dalam kegiatan pembelajaran.

b. Pelaksanaan Tindakan (action) (110 menit)

1) Peneliti melaksanakan pembelajaran sesuai perencanaan yaitu pembelajaran melalui Pembelajaran Berbasis Masalah

2) Memberikan orientasi permasalahannya kepada mahasiswa (10 menit)

3) Mengorganisasikan mahasiswa untuk meneliti (20 menit)

4) Membantu investigasi mandiri dan kelompok (30 menit)

5) Mengembangkan dan mempresentasikan artefak dan exhibit (30menit)

6) Menganalisis dan mengevaluasi proses mengatasi masalah (20 menit)

c. Pengamatan (observation)

Kegiatan observasi bertujuan untuk mendokumentasikan segala sesuatu yang berkaitan dengan kegiatan pembelajaran. Pada tahap ini, peneliti yang dibantu oleh seorang rekan peneliti melakukan observasi selama kegiatan pembelajaran berlangsung. Data yang ingin diperoleh pada tahap ini adalah selama proses pembelajaran berlangsung.

d. Refleksi (reflection).

Peneliti dan pengamat menganalisa hasil pengamatan pelaksanaan siklus I untuk mengetahui kekurangan atau kelemahan pelaksanaan kegiatan pembelajaran. Hasil refleksi ini digunakan untuk melakukan perbaikan pada pelaksanaan siklus II.

\section{Pembahasan}

Pada siklus I, materi yang dibahas adalah tentang integral lipat dua atas daerah peregi panjang beserta penggunaannya, yaitu mencari volume benda pejal integral lipat dua atas daerah persegi panjang. Berikutnya peneliti akan menggunakan pembelajaran berbasis masalah dalam menyampaikan materi kalkulus lanjut.

Hal yang perlu diobservasi pada tabel pengamatan di atas jika dikaitkan dengan pembelajaran berbasis masalah terletak pada kegiatan diskusi terutama pada masalah mengajukan dugaan dan melakukan inkuiri pada siklus I ini diatas dapat kita simpulkan bahwa dengan menggunakan pembelajaran berbasis masalah hasil observasi setiap indikator pada siklus I masih mempunyai nilai rendah, terutama pada masalah mengajukan dugaan dan melakukan inkuiri. Sebagian besar mahasiswa masih kurang tepat dalam mengajukan dugaan, hal itu disebabkan karena sebagian mahasiswa masih kurang tepat dalam menggambar ruang dimensi tiga dan menentukan batasan integrasinya karena sebagian besar mahasiswa kurang paham cara menggambar bangun benda pejal dari permasalahan yang diminta. Berdasaarkan hasil observasi pada siklus pertama maka perlu diberi tambahan bahwa pada siklus kedua nanti yaitu pada tahap 
kegiatan diskusi terutama pada masalah mengajukan dugaan dan melakukan inkuiri.

Hasil nilai pos tes pada siklus pertama terlihat sebagian besar mahasiswa masih memperoleh nilai yang rendah, hal tersebut tentu saja merupakan indikasi dari hasil pengamatan observer yang menyatakan bahwa sebagian besar mahasiswa masih sangat kurang dapat mengeluarkan ide atau gagasan secara optimal dalam kegiatan diskusi, sehingga mahasiswa belum dapat menyelesaikan permasalahan integral lipat dua atas daerah persegi panjang. Dalam mengatasi masalah tersebut dosen merencanakan suatu Satuan Acara Perkuliahan (SAP), yang mana SAP tersebut dapat meningkatkan tingkat berfikirnya. Salah satu hal yang perlu ditambahkan adalah dosen meminta setiap mahasiswa untuk mengeluarkan idenya ketika berdiskusi dengan kelompoknya dengan memberikan pancingan berupa pertanyaan-pertanyaan secara langsung pada mahasiswa.

Berdasarkan hasil observasi pada siklus yang kedua terutama pada kegiatan diskusi yang di dalamnya terdapat kegiatan mengajukan dugaan dan melakukan inkuiri sudah cukup baik, hal tersebut dapat dilihat pada tabel observasi yang menunjukkan bahwa kegiatan mahasiswa pada tahap tersebut mengalami kenaikan, sehingga terlihat pada hasil tes akhir menunjukkan bahwa terjadi kenaikan rata-rata nilai mahasiswa.

Kenaikan nilai mahasiswa mengindikasikan bahwa terdapat peningkatan aktifitas intelektual mahasiswa, yaitu pada tahap berdiskusi. Pada kegiatan berdiskusi, mahasiswa dapat memberikan masukan, ide, saran dan gagasangagasan yang menurut mereka benar, meskipun belum diketahui kebenaranya tersebut, akan tetapi dengan melalui tahapan pada sintaksis model pembelajaran tersebut, mahasiswa mempunyai ide, gagasan yang akan meningkatkan kemampuan berfikir tingginya. Pada siklus ke dua ini, mahasiswa telah dapat menunjukkan peningkatannya dalam berfikir, sehingga apabila diterapkan model pembelajaran berbasis masalah ini secara kontinu, maka akan diindikasi dengan peningkatan berfikir mahasiswa dalam menyelesaikan masalah kalkulus lanjut.

Dari instrumen hasil tes prestasi belajar telah diketahui bahwa pada siklus I, ketika pada permasalahan dalam menghitung integral lipat 2 atas daerah bukan persegi panjang, mahasiswa mengalami kesuliatan terutama terkait dengan masalah penyelesaian integralnya. Sebagian besar mahasiswa lupa cara menyelesaikan perhitungan integral yang mana masalah itu merupakan mareri prasyarat, yaitu pada materi penyelesaian integral pada mata kuliah kalkulus II. Sehingga mahasiswa haruslah mengingat kembali tentang materi kalkulus II. Dalam hal ini dosen ikut berperan sebagai motivator dan fasilitator agar mahasiswa mengingat dan belajar kembali tentang materi kalkulus II.

Pada siklus II, setelah dilakukan refleksi dengan observer dapat berjalan lebih baik, dengan melakukan perbaikan dari siklus sebelumnya, yaitu pada siklus I. Pembelajaran Berbasis Masalah merupakan metode pembelajaran aktif yang digunakan untuk masalah terstruktur yang merupakan tanggapan dari hasil 
pembelajaran.Pada model pengajaran ini, digunakan untuk menyelesaikan masalah mempunyai struktur yang kompleks yang tidak cukup bila dikerjakan dengan algoritma yang sederhana. Pada Pembelajaran Berbasis Masalah ini, mahasiswa diberi kesempatan untuk mengembangkan kemampuannya sendiri. Sehingga apabila pada siklus I mahasiswa mengalami kesulitan dalam menyelesaikan masalah integralnya, pada siklus II cukup terlihat mahasiswa sudah dapat menentukan bangun benda pejalnya, menentukan batasan dan menyelesaikan perhitungan integralnya.

Pada siklus II, materi yang dibahas adalah integral lipat dua atas daerah bukan persegi panjang dan penggunaannya dalam menentukan volume benda pejal. Materi tersebut merupakan materi yang sangat memerlukan pemahaman konsep. Penggunaan materi prasyarat sangat menentukan pada pemecahan mencari volume dengan menggunakan integral lipat dua ataupun integral lipat tiga. Dalam menentukan volume, mahasiswa dituntut untuk memahami materi prasyarat yaitu geomatri analitik. Tahap berikutnya setelah proses menggambar bangun benda pejal selesai, mahasiswa harus dapat menentukan batasan-batasan dari gambar bangun pejal tersebut serta menghitung integalnya. Perhitungan integral itu sendiri tidak bisa lepas dari materi kalkulus II. Proses berfikir mahasiswa mulai dari menggambar bangun pejal yang melibatkan materi dimensi tiga, hingga menghitung hasil akhirnya dengan menggunakan perhitungan integral sangat terlihat ketika dosen menyampaikan dengan pembelajaran berbasis masalah. menurut observer, kemampuan berfikir dalam menyelesaikan masalah yang komplek seperti pada materi kalkulus lanjut. Pada siklus II ini, diskusi mahasiswa sudah cukup terlihat baik, berdasarkan hasil observasi interaksi antar mahasiswa dalam satu kelompok tersebut sudah cukup baik dan aktif. Dosen secara aktif mendatangi setiap kelompok dan berdiskusi, serta memberikan pertanyaan kepada mahasiswa secara langsung pada anggota diskusi tersebut, memberikan pengaruh yang baik, sehingga mahasiswa termotivasi untuk belajar sehingga aktif dalam mengeluarkan ide ketika berdiskusi. Tentu saja hal tersebut berpengaruh pada peningkatan berfikir mahasiswa.

\section{Kesimpulan dan Saran}

\section{Kesimpulan}

Berdasarkan rumusan masalah dan pembahasan hasil penelitian pada maka dapat disimpulkan sebagai berikut :

Mata kuliah kalkulus lanjut yaitu pada materi integral lipat dua dan tiga serta penggunaannya merupakan mata kuliah yang mempunyai cara penyelesaian yang kompleks yang membutuhkan beberapa disiplin ilmu. Pembelajaran berbasis masalah mempunyai peranan yang sangat kuat dalam menghadapi kompetensi tingkat tinggi dalam memenuhi kebutuhan pemerintah, pasar dan industri.Secara umum tujuan dari pembelajaran berbasis masalah ada dua, yang pertama untuk menaikkan pengetahuan secara mendalam dari isi suatu materi, yang kedua mengembangkan berfikir tingkat tinggi siswa. 
Berdasarkan hasil observasi pada penelitian ini model pembelajaran berbasis masalah dapat meningkatkan kemampuan berfikir tingkat tinggi mahasiswa pada materi integral lipat dua dan tiga serta penggunaannya pada perkuliahan kalkulus lanjut.

2. Saran

Untuk meningkatkan kualitas perkuliahan kalkulus lanjut pada mahasiswa pendidikan matematika, maka penulis memberikan saran-saran sebagai berikut.

1. Untuk Perguruan Tinggi

Perlu dikembangkan dan diterapkan model pembelajaran yang melibatkan keaktifan mahasiswa, misalnya model pembelajaran Berbasis masalah sehingga dapat memacu mahasiswa untuk lebih aktif dalam proses perkuliahan sehingga dapat meningkatkan mutu perkuliahan

2. Untuk Mahasiswa.

Diharapkan dalam mempraktikkan model Pembelajaran Berbasis Masalah mengikuti secara aktif sehingga dapat digunakan sebagai sarana untuk berlatih aktif dalam proses belajar sehingga dapat memperoleh pengalaman yang baru.

3. Untuk Dosen

Dalam usaha meningkatkan mutu perkuliahan hendaknya dosen menggunakan model pembelajaran Berbasis Masalah, khususnya mata kuliah kalkulus lanjut 